\title{
Genéza a hodnoty literatúry a kultúry národného spoločenstva
}

\author{
Viera Žemberová (Prešov)
}

Marek Mitka - Ivana Slivková (eds.): Transformácia národných literatúr a kultúr v stredoeurópskom kontexte (1780 - 1890). Zborník príspevkov z medzinárodného vedeckého seminára konaného 9. 11. 2017 na Filozofickej fakulte Prešovskej univerzity v Prešove. Prešov: Vydavatel'stvo Prešovskej univerzity, 2019. 200 s. ISBN 97880-555-2246-3.

Iniciátorom lustrovaného, literárnovedne zameraného zborníka jedenástich autorov prevažne zo slavistického výskumu je náročný projekt smerujúci k vzniku Slovnika stredoeurópskych kultúr I. (1780-1890) na akademickej pôde. Zborník vznikol v súlade s výskumnou a vzdelávacou orientáciou organizátorov medzinárodného vedeckého seminára z Inštitútu stredoeurópskych štúdií na Filozofickej fakulte Prešovskej univerzity v Prešove.

Náročnosṫ pripomenutého výstupu vo forme slovníka zaznamenal transformáciu entít národných kultúr vo vymedzenom geografickom priestore a čase, a tá spočíva v (ne)súčinnosti predovšetkým vývinových podmienok aktualizovaných vybratých národných spoločenstiev, ktoré sa autori príspevkov rozhodli jednak rekonštruovat alebo komentovat spoločným termínom stredoeurópsky kontext. Priestor, do ktorého autori jednotlivými témami svojich príspevkov vstupujú, vymedzuje historiografický údaj odkazujúci na koniec 18. storočia až po doznievanie 19. storočia, d’alej vývinová a javová identita odlišných národných literatúr a kultúr pri aplikovaní tých metodologických inštrukcií, ktoré poskytujú zo spoločenských vied predovšetkým literárna história a historiografia.

Geografický priestor, historiografický výskum, kultúrne dejiny, literárny dejepis a sondy do dejín lingvistiky sú tie komponenty stredoeurópskeho kontextu, jeho/ich prirodzenej odlišnosti, ktoré vymedzili jednotlivé príspevky zverejneným časovým údajom 1780-1890. Aktualizované národné spoločenstvá vymedzené časové obdobie prežili v odlišných podmienkach s rozličnými následkami či dôsledkami, ktoré sa včlenili do celku tradovanej podstaty identity, priestoru, jazyka, politickej normy, vztahu k tradícii a $\mathrm{k}$ híbke už známeho a dostupného literárnovedného výskumu. A práve ním, jeho časovým a javovým nerešpektovaním a nepričinením sa o vymedzenie postupov literárnovedného medziliterárneho a komparujúceho kontextu, ide o vedomé a voči téme zborníka nekontextové otváranie časových a aj s témou zborníka nesúvisiacich informačných súborov o pohyboch, v tej ktorej literatúre až do 20. storočia, ba aj do 21. storočia.

Autormi prevažujúco prierezových príspevkov, ktoré sú prirodzene zahltené sekundárnymi a príčinne sa aj opakujúcimi súvislostami (kontext bez porovnávacej pointy) o ukrajinskej, mad’arskej, českej, pol'skej, slovenskej, karpatorusínskej literatúre, sú v prevahe predkladané učebnicové, výskumom oddávna uchovávané informácie z jednotlivých národných či európskych kultúrnych priestorov aj s reáliami až po 21. storočie, čím príspevky ako celok utvorili referenčnú ponuku na „dopovedanie“ toho, čím ten ich vývin pokračuje poza vymedzenie kultúrnych a spoločenských etáp zachytených obsahmi - znova odlišných podstát vývinových období - pomenovaných ako osvietenstvo, národné obrodenie, niektorý z dobových -izmov atd'.

Geografická, politologická, historiografická, literárnovedná, kulturologická aj viaceré d’alšie spoločenskovedné vymedzovania, aké naznačujú rozložitosî/ posuny/ presuny pri konkrétnom, či pri parciálnom chápaní alebo vymedzení, no zvlášt pri aplikovaní javu stredoeurópsky kontext, ponúka sa nemálo národných a kontextových presunov medzi 18. storočím a 19. storočím až po súčasnost' bez vývinovej, hodnotovej etnickej, kultúrnej pointy, ktorú si zborník žiadal pre celostnost’ svojej náučnej funkcie. Vyňaté reálie z politických a kultúrnych dejín stredoeurópskeho priestoru (osvietenstvo, klasicizmus, romantizmus, realizmus) nepresadzujú autori príspevkov pri vymedzovaní dostredivej 
súčasti toho, čo očakávajú od kontextu predpokladané univerzálne následky zložitého vývinového procesu, jeho uplatnením sa na kontinente a v aktualizovaných národných literatúrach.

Autori príspevkov sa sústred’ujú na taký profil individuálneho chápania termínu kontext, ktorý uchováva odlišnost̉ aj jedinečnosṫ v literárnych dejinách nimi sledovaného spoločenstva ako etnický, jazykový, inštitucionálny, personálny, poetologický, estetický a kultúrny prierez aj tendenčne zvýrazňovanú mozaiku (odkazy na svetovú literatúru a národné literatúry) tých informácií, ktoré absorbuje zjednocujúci kultúrny a spoločenský jav osvietenstvo a po ňom nastupujúce kultúrne javy v nasledujúcich storočiach v jednotlivých literárnych a kultúrnych spoločenstvách dostredivého stredoeurópskeho kultúrneho kontextu.

Pravdepodobne (ne)uvedomenie si vývinovej a javovej premeny podstaty dostupných a v odbornej verejnosti známych literárnohistorických informácií uložených do ustáleného spojenia stredoeurópsky kontext neprinieslo podstatnú a záväznú informáciu voči téme zborníka, teda i to, čo sa týmto spojením objektívne rozumie v historiografii a v národných konceptoch literárnej histórie v exponovanom intervale rokov 1780-1890 a v tých rokoch, ktoré nasledovali $\mathrm{v}$ d'alších storočiach a v rozličných vývinových hodnotách národných literatúr a kultúr sústredených do transformácie a do stredoeurópskeho kontextu ako do metodologického problému iniciovaného odlišnostou časti a celku pri uskutočňovaní dialógu mentálne, jazykovo, organizačne spravidla nesúrodých reálií a špecifických súvislostí.

Ak prijmeme naznačený postup autorov jednotlivých príspevkov, potom s porozumením treba prijat predložený súbor príspevkov pre odbornú verejnost', ale zvlášt a predovšetkým pre študentov danej problematiky formou učebnicového náčrtu, či ako kultúrnu mozaiku informácií alebo ako etnický a jazykový prierez jedinečností uchovaných literárnou vedou a dejinami o konkrétnej národnej kultúre.

V tieni prevažujúcich rekonštrukčných prierezov z dejín národnej literatúry zostali metódou riešenia svojej témy osihotené tie príspevky, ktoré sa sústredili na interpretáciu nazeracieho, poetologického a literárnoestetického prejavu generácie, autora, druhu, žánru, textu, programu ako súčastí iniciačného vkladu jednotlivcov do literárneho a kultúrneho dialógu a kontaktu na nadčasovej osi cudzie - národné, teda za reálnym a vývinovým časovým horizontom kultúrneho a literárneho kontextu aj špecifickej transformácie spoločenského (univerzálneho) obsahu termínu osvietenstvo. Napokon ide o referenčné vstupy do zvolenej témy medzinárodného seminára a jemu venovaného zborníka, a táto skutočnost’ odkazuje na zistenia naviazané na minulé a súčasné storočie.

Zborník venovaný transformácii jednotlivých národných literatúr a kultúr autenticky pôsobiacich v stredoeurópskom priestore a v kontexte vývinom vymedzených rokov 1780-1890 vykoná záslužnú vzdelávaciu misiu medzi tými, ktorí študujú problematiku mnohonárodnej európskej kultúry. V tejto súvislosti je potrebné pripomenút autorom príspevkov, že nimi tento výskum nezačal a ani nezačína, čo by mala naznačit odborná literatúra, s ktorou sa vypravili do národnej literárnej vedy a do dostupného výskumu svojich predchodcov v literárnej histórii, ked' sa sústredili na výskum a identifikovanie procesov a jedinečností v európskej spoločnosti dávnych storočí.

\section{prof. PhDr. Viera Žemberová, CSc.}

Inštitút slovakistiky a mediálnych štúdií

Filozofická fakulta, Prešovská univerzita v Prešove

Ul. 17. novembra 1, 08000 Prešov, Slovensko

viera.zemberova@ff.unipo.sk

Toto dílo Ize užít v souladu s licenčními podmínkami Creative Commons BY-SA 4.0 International (https://creativecommons.org/licenses/by-sa/4.0/legalcode). Uvedené se nevztahuje na díla či prvky (např. obrazovou či fotografickou dokumentaci), které jsou v díle užity na základě smluvní licence nebo výjimky či omezení přislušných práv. 